\title{
Effectiveness of targeted viral load strategy in a public health HIV/AIDS programme
}

\author{
Rajyasree De ${ }^{1}$, Nivedita Dutta', Dolanchampa Modak', Shantasil Pain², Sripati Dasmohapatra ${ }^{3}$, Sukamal Bisoi ${ }^{4}$, \\ Subhasish Kamal Guha ${ }^{1 *}$
}

From 2nd International Science Symposium on HIV and Infectious Diseases (HIV SCIENCE 2014)

Chennai, India. 30 January - 1 February 2014

\section{Background}

Targeted viral load (VL) strategy is followed in the ART programme of India. Patients failing antiretroviral therapy, undergo VL testing and switched to 2ndline ART if $\mathrm{VL}$ is $>5000$ copies $/ \mathrm{ml}$.

\section{Methods}

Data of patients referred to School of Tropical Medicine, Kolkata for suspected treatment failure (TF) was analyzed for the period of December2008 to November2013 to ascertain the positive predictive value (PPV) of immunologic and/or clinical parameter for confirming virologic failure (VF) and to observe the short term outcome of secondline treatment. Paired t- test was used for data analysis.

\section{Results}

VF was noted in 287(51.3\%) of 560 patients (median age 37 years; male-436(77.85\%); median CD4 109 cells $/ \mathrm{mm}^{3}$ at suspected TF. Number of patients failing by immunologic, clinical and clinicoimmunologic criteria was $414(74 \%)$, $11(2 \%)$ \& 135(24\%) respectively with corresponding PPV of $48 \%, 46 \%$ \& $63 \%$ respectively. PPV of CD4 falling below baseline, $>50 \%$ drop from on-treatment peak value and failure to reach 100 cells $/ \mathrm{mm}^{3}$ after 12 months of ART was $37 \%, 55 \%$ and $25 \%$ respectively. Among 216 patients with minimum 6 months follow-up, the median CD4 \& VL changed significantly following 6 months of secondline ART (103.5 to 232 cells $/ \mathrm{mm}^{3} ; p<0.0001$ and 4.04 to 2.6 $\log _{10}$ copies; $p<0.0001$ respectively). Undetectable VL was achieved in $164(76 \%)$. Out of 284 patients starting secondline ART, 25 (8.8\%) died within 6 months.

\footnotetext{
* Correspondence: drskguha@gmail.com

${ }^{1}$ Centre of Excellence in HIV Care, Calcutta School of Tropical Medicine, Kolkata, West Bengal, India

Full list of author information is available at the end of the article
}

\section{Conclusion}

Immunoclinical criteria have low PPV in diagnosing VF. Despite late switch, majority (76\%) could achieve undetectable VL at 6 months but the high early mortality $(8.8 \%)$ is a concern.

\section{Authors' details}

${ }^{1}$ Centre of Excellence in HIV Care, Calcutta School of Tropical Medicine, Kolkata, West Bengal, India. ${ }^{2}$ Department of Medicine, North Bengal Medical College, Darjeeling, West Bengal, India. ${ }^{3}$ Care, Support \& Treatment Division, West Bengal State AIDS Prevention \& Control Society, Kolkata, West Bengal, India. ${ }^{4}$ Department of Community Medicine, RG Kar Medical College, Kolkata, West Bengal, India.

Published: 27 May 2014

\section{doi:10.1186/1471-2334-14-S3-022}

Cite this article as: De et al:: Effectiveness of targeted viral load strategy in a public health HIV/AIDS programme. BMC Infectious Diseases 201414 (Suppl 3):O22.
Submit your next manuscript to BioMed Central and take full advantage of:

- Convenient online submission

- Thorough peer review

- No space constraints or color figure charges

- Immediate publication on acceptance

- Inclusion in PubMed, CAS, Scopus and Google Scholar

- Research which is freely available for redistribution

Submit your manuscript at www.biomedcentral.com/submit
( Biomed Central 